\title{
ON-LINE MONITORING OF TECHNOLOGICAL PROCESS OF MATERIAL ABRASIVE WATER JET CUTTING
}

\author{
Daniel Kinik, Beáta Gánovská, Sergej Hloch, Peter Monka, Katarína Monková, Zuzana Hutyrová
}

Original scientific paper

The paper deals with the indirect ways of on-line monitoring of technological processes of cutting. The objective of the study is a design of on-line monitoring system for the cutting technology through an abrasive water jet. In cutting by the abrasive water jet two parallel phenomena are formed. The phenomena are represented by generated surface and vibrations. For the purpose of proving of the hypothetical assumptions on dependence of generated surface quality on vibrations the experiments utilizing stainless steel AISI 304 were performed. The experiments were realized at four diverse settings of cutting head traverse speed. The material vibrations were collected by means of two independent accelerometers PCB IMI 607 A11. One of the accelerometers was oriented towards the cutting direction and the other in direction perpendicular to cutting. Sampling frequency was of $30 \mathrm{kHz}$. The generated topography of the material was measured by an optical profilometer FRT MicroProf. The collected data were evaluated by a virtual tool developed in LabView 8.5 in the form of vibration analyses being consequently mutually compared. Both phenomena proved to be dependent on common technological cause, i.e. on cutting head traverse speed. At the same time the study offers a theoretical design of the on-line monitoring system and of the future heading of the research in this field.

Keywords: abrasive water jet; monitoring, on-line; vibrations

\section{On-line praćenje tehnološkog postupka rezanja materijala abrazivnim vodenim mlazom}

Izvorni znanstveni članak

Rad se bavi indirektnim načinima on-line praćenja tehnoloških postupaka rezanja u svrhu projektiranja on-line sustava praćenja primjenom tehnologije rezanja abrazivnim vodenim mlazom. Rezanjem abrazivnim vodenim mlazom javljaju se dva fenomena, a to su generirana površina i vibracije. U svrhu dokazivanja hipotetske pretpostavke ovisnosti kvalitete generirane površine o vibracijama, provedeni su eksperimenti s nehrđajućim čelikom AISI $304 \mathrm{~s}$ četiri različita podešavanja brzine prijelaza rezne glave. Vibracije materijala su se pratile pomoću dva odvojena akcelerometra PCB IMI 607 A11. Jedan je bio orijentiran na smjer rezanja, a drugi na pravac okomit na rezanje. Učestalost uzimanja uzorka bila je $30 \mathrm{kHz}$. Dobivena topografija materijala mjerena je optičkim profilometrom FRT MicroProf. Dobiveni su se rezultati proračunavali virtualnim alatom razvijenim u in LabView 8.5 u obliku analiza vibracija koje su se stalno međusobno uspoređivale. Pokazalo se da obadva fenomena ovise o zajedničkom tehnološkom razlogu, t.j. brzini prijelaza rezne glave. U isto vrijeme u radu se daje teoretski projekt on-line sustava praćenja i smjer budućeg istraživanja u ovom području.

Ključne riječi: abrazivni vodeni mlaz; on-line; praćenje; vibracije

\section{Introduction}

The paper was written pursuant to constant increase of quality and production requirements. The increase demands the system design which would produce highquality products cheaply and fast. The fact is that quality is many times linked with the higher price level and thus fully flexible system able to eliminate purposeless production costs $[1,2,3,4,5]$. One of the alternatives of generation of such system or at least of getting closer to it is introduction of on-line monitoring into already existing conventional and unconventional technological processes. The abrasive water jet cutting (AWJ) ranks among the unconventional technological processes of material cutting $[1,7,11,13,14]$. This technological process is currently being pushed to the foreground since any available material is possible to be cut by the technology [6]. The advantages of AWJ technology rest not only in low impact upon environment, but in non-occurrence of temperature changes in the cutting trace $[12,15]$. As any other technological process even the AWJ technology is during cutting accompanied by the attendant phenomena such as vibrations or acoustic emissions. Therefore the aim of the paper is focused on the analysis and comparison of data acquired through the experimental measurements of vibrations and of their utilization in theoretical design of feasible method of on-line monitoring of the given technological process.

\subsection{State of the art analysis}

The problems related to the technology of abrasive water jet cutting represent objects of concern of research and development of many authors. However, the subject of their interest is chiefly typical topography of the generated surface and the effort to control and to predict the surface topography right at the beginning of cutting process.

At the beginning of the introduction of AWJ technology into practice the initial researches of the authors were oriented mainly towards the material removal mechanism. The issue represented a concern to the authors such as Hashish [8], Chao and Geskin [28], Arola and Ramulu [6]. Boud et al. [17] concentrated on the study of morphology and mechanical properties of the abrasive (abradant) and on the finished surface in case of titanium alloy cutting. The surface generated during cutting of glass fibre of epoxide composites was examined by the authors Azmir et al. [18]. Momber [11], Mohan [19], Kovacevic [20], as well as Hassan [7] and Arulu [21] focused their attention on the accompanying phenomenon of acoustic emission with the aim of its utilization in cutting depth monitoring in abrasive water jet cutting of material. In 1998 the analytical model of the overall cutting depth was elaborated by the authors [22]. In 2001 Dasgupta et al. [23], Neelesh and Vijay [24] developed the analytical models of simulation, planning and optimization and on the basis of the particular type of operation, material, and conditions of machining they 
compiled selections of the appropriate models. Sharma et al. [12] used the Taguchi proposal of experiments to create a cutting model for the specified material group.

In 2007 Valíček et al. [10] oriented towards the formation of optical method of detection and analysis of geometrical parameters of topography of surface generated in the course of abrasive water jet cutting of material. The materials were classified according to cutability $T_{C U T}$. Furthermore, they designed a system of feedback control with regard to the measured values of acoustic pressure $L a_{e q}$. Arulu et al. [21] and later Folkes [25] used the acoustic emission for the on-line detection of a workpiece state. The acoustic emission and vibrations were examined by Hloch et al. [9] and Valíček et al. [26]. Authors give their attention also to the influence of factors upon unevenness of surface of stainless steel and aluminium [9].

Acoustic emissions as well as vibrations achieved success in diagnostics, prediction, and control of a number of technological procedures. Out of all present phenomena occurring in material machining chiefly acoustic emissions were applied in research. Already in 1992 author's [20] centre of attention was indirect monitoring of depth of penetration into wooden material in case of which normal forces generated on a workpiece were used as an indicator. Momber et al. [11] utilized acoustic emission for the on-line monitoring of the AWJ process of cutting of material disturbed by breakage. To measure the diffused energy $R M S$ value was used. Authors [1] examined the alternatives of on-line control and prediction of the surface quality through the negative phenomenon - noise. In 2002 Ativitavas [32] devoted his study to linkage of acoustic emissions with the neural network to determine defects in plastic composite structures. In 2004 Asraf's study [26] offered a designed model of the continual cutting depth monitoring through acoustic emission in the AWJ process and at the same time he discovered that the $R M S$ value increased linearly along with the growing cutting depth. Another author dealing with acoustic emission was Arulu et al. [21] who paid attention to the process of composite drilling.

Just a minor group of authors was concerned with material vibrations and information included in the process of abrasive water jet cutting. By the analysis of vibration spectrum in the process of abrasive water jet cutting Hloch et al. designated frequency components carrying significant information on instant condition of the cutting process. The vibrations occurring in such cutting got into the centre of attention of Hreha et al. [15, 28, 29, 30]. Hreha studied surface roughness parameters $R a, R q$ and $R z$ and consequently, through vibrations authors studied the processes occurring during penetration of water jet through material. A team of authors pointed out the possibilities of utilization of vibrations as of information carriers for the on-line control of abrasive water jet cutting of material and at the same time the alternatives of the cutting technology utilization were presented.

\section{Objectives of the paper}

The objective of the paper is a design of indirect method of on-line monitoring of technological processes of cutting with the application in technology of material cutting by abrasive water jet through the accompanying phenomenon - vibrations. To meet the objective of the study it is inevitable to perform experimental measurements and to process the data of the experiments. Consequently, the data are necessary to be reciprocally compared by means of which the dependence between traverse speed of cutting head and generated surface quality will be detected. Last but not least both the possible method of on-line control and regulation of the particular technological process are important to be designed.

\section{Experimental study}

During the experiment stainless steel AISI 304 was used as an experimental material. The workpiece in case of which the measurements were performed was a plate with dimensions of $100 \times 150 \times 12 \mathrm{~mm}$. In the course of the experiment the plate was cut four times in total by the method shown in Fig. 1.
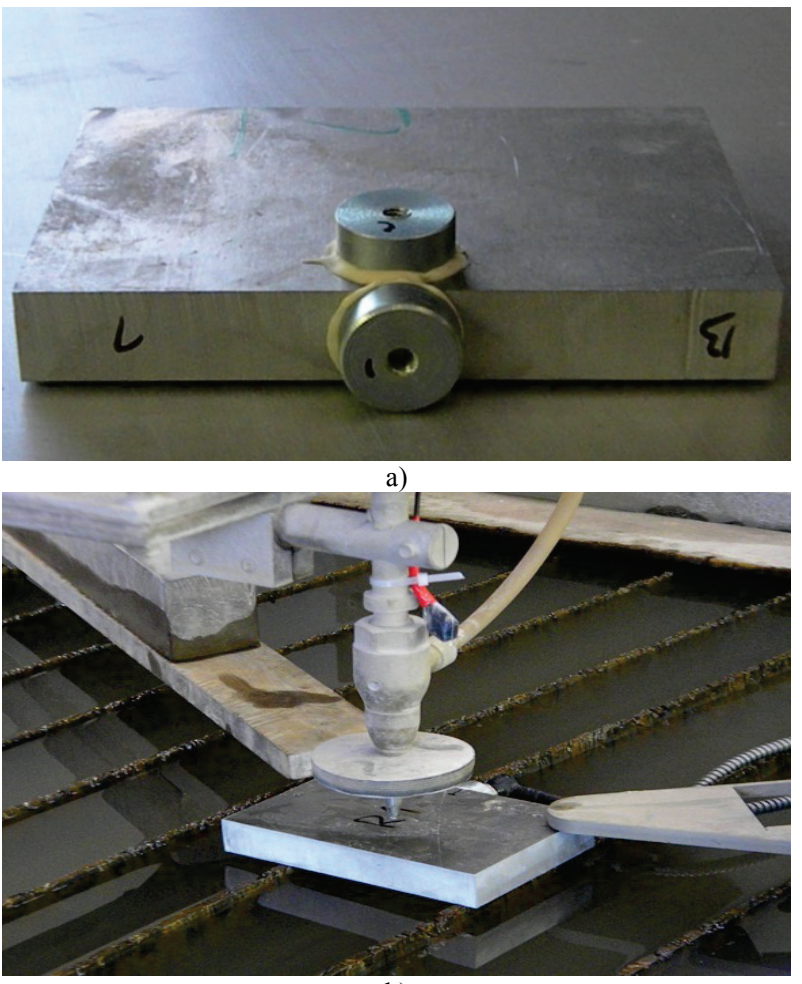

b)

Figure 1 Experimental set up a) sensors placed on material, b) detail on cutting head and material being cut

Collection of data inevitable for more profound analysis of vibrations was repeatedly performed several times. Two sensors placed directly on a workpiece (one was fixed axially and the other radially) served as data collectors in the form of accelometers PCB IMI of series type of 607 A11 with an integrated cable. The sensitivity of the sensors was of $100 \mathrm{mV} / \mathrm{g}$ and their frequency range was of up to $10 \mathrm{kHz}$. These sensors were connected to the measurement system of NI PXI. The system consisted of the measuring card PXI 4472B and was typical for the 8channel simultaneous collection and 24 bit analogue and digital converter. 
The sampling frequency of the system was of 102 $\mathrm{kHz}$ with the dynamic range of $110 \mathrm{~dB}$. The frequency analyser SKF Microlog Gx-S was used for the performance of verification and calibration measurements in case of which the analysis of the measured data was realized through the program equipment of SFK Aptitude Analyst. Measurement of the profile parameters of surfaces generated by the particular technology was carried out by means of optical contactless method through the optical profilometer Microprof FRT by the producer Fries Research \& Technology $\mathrm{GmbH}$ that allowed 3D evaluation of the surface.

The experiment was performed under environmental and technological conditions presented in the Tabs. 1 and 2.

Table 1 Environmental conditions

\begin{tabular}{|l|c|c|}
\hline \multicolumn{1}{|c|}{ Factors } & $\begin{array}{c}\text { Symbol } \\
\text { (Quantity) }\end{array}$ & Value \\
\hline Pressure & $p / \mathrm{MPa}$ & 1007 \\
\hline Temperature & $C /{ }^{\circ}$ & 21 \\
\hline Air moisture & $\%$ & 38 \\
\hline Altitude & $\mathrm{m}$ & 280 \\
\hline Geographical position & - & $49^{\circ} 00^{\prime} 00^{\prime \prime}$ \\
& & $21^{\circ} 14^{\prime} 00^{\prime \prime}$ \\
\hline
\end{tabular}

Table 2 Technological conditions

\begin{tabular}{|l|c|c|}
\hline \multicolumn{1}{|c|}{ Factors } & $\begin{array}{c}\text { Symbol } \\
(\text { Quantity })\end{array}$ & Value \\
\hline Pressure & $p / \mathrm{MPa}$ & 350 \\
\hline Traverse speed & $v / \mathrm{mm} / \mathrm{min}$ & $50 ; 75 ; 100 ; 150$ \\
\hline $\begin{array}{l}\text { Abrasive mass flow } \\
\text { rate }\end{array}$ & $m_{a} / \mathrm{g} / \mathrm{min}$ & 250 \\
\hline $\begin{array}{l}\text { Material thickness } \\
\text { (stainless steel) }\end{array}$ & $b / \mathrm{mm}$ & 12 \\
\hline $\begin{array}{l}\text { Abrasive type } \\
\text { (Barton Garnet) }\end{array}$ & $M E S H$ & 80 \\
\hline Standoff & $z / \mathrm{mm}$ & 2 \\
\hline Focusing tube & $d_{\mathrm{f}} / \mathrm{mm}$ & 0,8 \\
\hline Orifice & $d_{\mathrm{o}} / \mathrm{mm}$ & 0,3 \\
\hline
\end{tabular}



Figure 2 Simplified representation of the experiment

In the frame of the experiment it was inevitable to monitor and to record the change of formed vibrations at the point of sensor fixation in dependence on cutting conditions by the system of NI PXI. Fig. 2 shows the model of experimental set up of the process. Four measurements were performed with diverse setting of traverse speed of cutting head $(v=50 \mathrm{~mm} / \mathrm{min}, v=75$ $\mathrm{mm} / \mathrm{min}, v=100 \mathrm{~mm} / \mathrm{min}, v=150 \mathrm{~mm} / \mathrm{min}$ ).

\section{Results and discussion 4.1 Surface topography analysis}

As per graphic dependences it is clear that with the growing depth the overall numerical development of the individual roughness profile parameter of the generated surface changes as well. The phenomenon is caused by the fact that with the growing depth the jet acting upon the material gradually loses its energy and thus its higher curvature in larger depths occurs and at the same time surface quality in the particular depth lines declines.

Roughness parameters $R a, R q, R z$ were measured in 21 depth lines of the $20 \mathrm{~mm}$ long segment marked by green boundaries. The red boundary represents the end of the sample cutting (Fig. $3 \mathrm{~A} \div$ Fig. 3D). If the dependence of the surface profile parameters $R a, R q$ and $R z$ on cutting depth at speed of $v=50 \mathrm{~mm} / \mathrm{min}$ is compared with dependence of the surface roughness parameters $R a, R q$ and $R z$ on cutting depth at speed of $v=150 \mathrm{~mm} / \mathrm{min}$ (Fig. 3E, Fig. 3F) from the perspective of the influence of speed upon the development of the values of these parameters, it might be stated that apart from the cut depth the development of the values of roughness parameters is significantly affected by speed at which the cutting head moves in the course of cutting. At speed of $v$ $=50 \mathrm{~mm} / \mathrm{min}$ it could be observed that the development of the aforementioned parameters is more linear contrary to the case in which the speed was set to the value of $v=$ $150 \mathrm{~mm} / \mathrm{min}$. The phenomenon is possible to be explained from the point of view of interaction between a high-speed permeate and a workpiece. At traverse speed of cutting head of $v=50 \mathrm{~mm} / \mathrm{min}$ the abrasive water jet disposed of sufficient amount of time to make the abrasive particles capable of even and intensive erosion of the material surface along the entire depth of cutting sample which is not applicable at traverse speed of $v=$ $150 \mathrm{~mm} / \mathrm{min}$. The combination of higher traverse speeds of cutting head with larger depth of the cut causes disability of the jet to erode the material surface of cutting sample to satisfactory extent and that is in consequence demonstrated by the formation of striated zone the roughness of which is not sufficient from the perspective of input requirements for surface quality.

\subsection{Analysis of detected vibrations}

The elaborated developments of vibration signals are divided into two groups (Fig. 3). The first group includes the data measured by sensor S1 (Fig. 3A, Fig. 3C) which was fixed on the cutting material in axial direction and the second group contains the data measured by sensor S2 (Fig. 3B, Fig. 3D) fixed on the material in radial direction. Through the comparison of these time developments at speeds of $v=50 \mathrm{~mm} / \mathrm{min}$ and $v=150 \mathrm{~mm} / \mathrm{min}$ it is possible to state that at lower traverse speed of the cutting head the development of amplitude of vibration oscillations is more stable contrary to higher speeds and this fact opens the door for further research for the purpose of detection of utilizable vibration spectrum 
(inevitable is to determine the utilizable vibration spectrum both at lower and higher traverse speeds of cutting head) for the application of on-line monitoring of the particular technological process. Out of these developments the changes of amplitude of vibration signal oscillations is obvious not only in dependence on the means of the sensor fixation but also in dependence on the traverse speed of cutting head.
A)

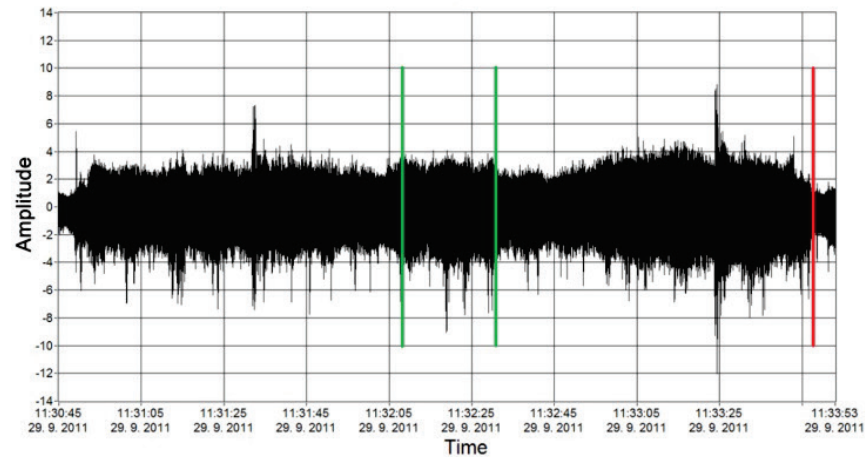

C)

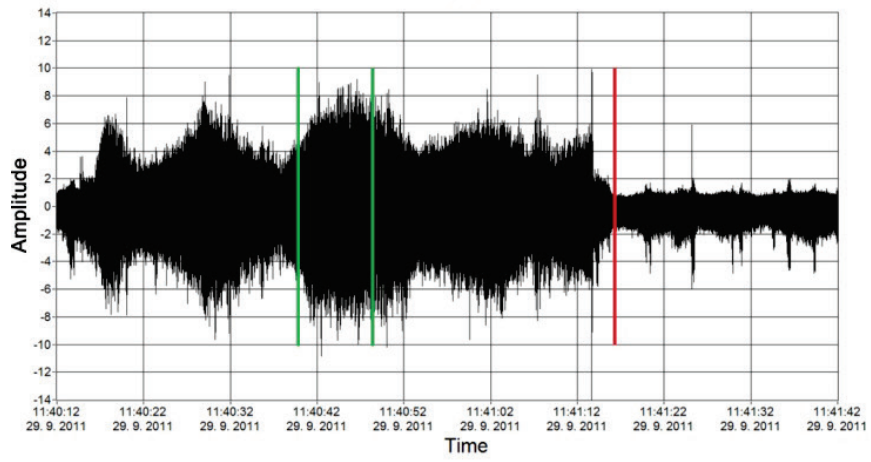

E)



B)



D)



F)

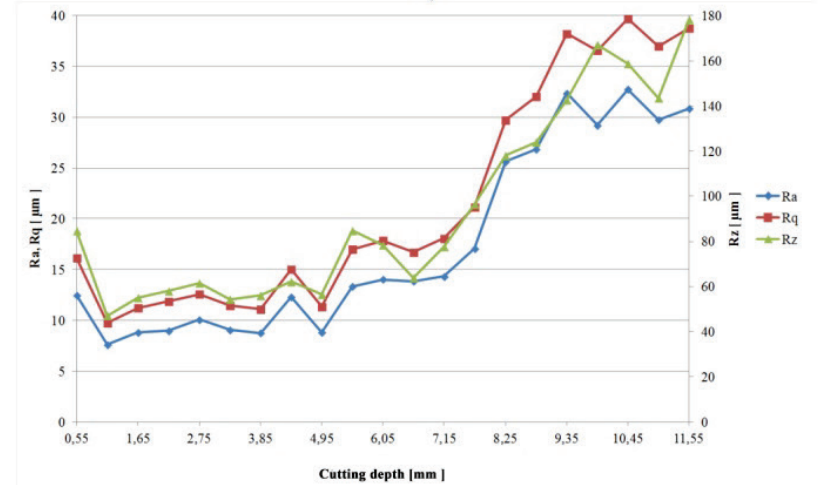

Figure 3 Time development of vibration signal: A) at traverse speed of $v=50 \mathrm{~mm} / \mathrm{s}-$ sensor S1; B) at traverse speed of $v=50 \mathrm{~mm} / \mathrm{s}-\mathrm{sensor} \mathrm{S2;} \mathrm{C)} \mathrm{at}$ traverse speed of $v=150 \mathrm{~mm} / \mathrm{s}$ - sensor S1; D) at traverse speed of $v=150 \mathrm{~mm} / \mathrm{s}$ - sensor S2; Dependence of roughness profile parameters: E) on cutting depth at traverse speed $v=50 \mathrm{~mm} / \mathrm{s} ; \mathrm{F}$ ) on cutting depth at traverse speed $v=150 \mathrm{~mm} / \mathrm{s}$.

5 Utilization of acquired knowledge for the solution proposal
The series of performed experiments was carried out with the aim to show the link between surface topography and vibrations. In dependence on acquired knowledge of 
the technology in question and pursuant to realized analyses the real existence of the link between vibrations and surface topography might be referred to. Such indirect link is influenced by variant setting of traverse speed of cutting head as with the change of the speed setting the changes of intensity of amplitude of oscillations during vibrations occur as well as changes of surface topography quality. At low speeds the amplitude of oscillations is lower contrary to higher speeds. At the same time the assumption was proved that at lower speeds the surface topography is of higher quality than at higher speeds since at higher speeds the abrasive water jet did not possess sufficient amount of time to be able to erode the material surface equally along the entire depth of the material.

The paper along with other existing studies and future research direction might provide certain basis for formation of both theoretical and practical method of online monitoring of the AWJ technology. Such method of on-line monitoring is possible to be demonstrated from the theoretical point of view, Fig. 4.



In case of proposal of on-line monitoring of AWJ technology it is inevitable to be particular about selection of adequate feedback. The established feedback regulation is required to take into consideration the time delay resulting from the need of processing and evaluation of the measured data. The proposal of correct feedback is significant due to prevention of repeated regulation of traverse speed of cutting head at points in case of which it is not desired.

\section{Conclusion and the future direction of the research}

Currently, the control of cutting process by AWJ technology is performed in so called off-line mode. In case of the off-line mode those are beforehand specified requirements for cutting quality of surface and the cutting quality is possible to be verified after material cutting. Although in the cutting by means of such technology the method of prediction of surface quality exists, it is still necessary to point out that only under certain conditions and due to diverse accompanying features of the technology and its complicated specification. At the same time through on-line control and regulation the working productivity will increase and potential defect occurring in the course of the system operation will be possible to be determined and thus the reject formation will be prevented (saving of costs related to rejects).

On-line monitoring is possible to be performed with the particular technology only indirectly by accompanying phenomena such as vibrations or acoustic emissions. The endeavour of the study was pursuant to performed experiments focused on vibration measurement to detect dependence between traverse speed of cutting head (the cause) and formation of vibrations and to find out the extent of influence of the aforementioned traverse speed upon final surface roughness of cutting material.

According to the acquired knowledge the existence of real option of vibration utilization in introduction of online monitoring of the AWJ technological process can be confirmed. However, it is necessary to mention that in general the introduction and utilizable proposal of functional method of on-line control in practice require performance of a number of experiments focused on evaluation of vibrations with diverse variants of setting of input process factors because the formation of vibrations and final surface roughness are except for the examined cause of traverse speed $v[\mathrm{~mm} / \mathrm{min}]$ influenced also by other factors, for instance, permeate pressure or abrasive type. Such experiments are also inevitable to be performed in case of materials other than that used in our experiment (stainless steel AISI 304) as formation and spread of vibrations along with the surface roughness depend even on material properties of the individual materials. At the same time it would be convenient to carry out the experiments in ideally isolated environment (under laboratory conditions) as well as in common environment (for instance, production hall in the proximity of main road) with the aim to reveal "strange 
vibrations - vibration zone" (main road vibrations, machine vibrations, etc.) that could negatively affect the development of on-line control and process regulation. With the idea of proposal of online control system a number of other open questions occur concerning, for instance, the appropriate proposal of feedback system since in on-line monitoring it is necessary to take into account even certain time delay of measured data processing and consequent repeated regulation of process quantities in occurrence of failure in the process.

Out of the aforementioned it is clear that the introduction of on-line monitoring into technological processes is not by far as simple as it might seem. In analysis of the measured data other outputs were gained as well which, however, were not possible to be presented in the paper due to the required amount of text. These outputs along with the need of other experiments with the aim to design and apply on-line monitoring of technological processes into practice represent a challenge for further direction of the authors of the paper. The processed data will be monitored and evaluated further on. The direction of the future research and its results will be presented in another study by these authors.

\section{Acknowledgement}

This work was supported by the Slovak Research and Development Agency under the contract No. APVV-20712. Experiments were carried under the support of Institute of clean technologies for mining and utilization of raw materials for energy use, reg. no. CZ.1.05/2.1.00/03.0082 supported by the Research and Development for Innovations Operational Programme financed by the Structural Funds of the European Union and the state budget of the Czech Republic, and with support for the long term conceptual development of the research institution RVO: 68145535. The authors would like to thank Institute of the Geonics Academy of Science of Czech Republic, v.v.i., Ostrava Poruba, Czech Republic for experiment realisation

\section{References}

[1] Krolczyk, G.; Legutko, S.; Gajek, M. Predicting the surface roughness in the dry machining of duplex stainless steel. // Metalurgija. 52, 2(2013), pp. 259-262.

[2] Krolczyk, G. et al. Effects of the disc processing technology on the vibration level of the chipper during operations. // Tehnicki vjesnik-Technical Gazette, vol. 21, 2(2014), pp. 447-450.

[3] Novak-Marcincin, J.; Novakova-Marcincinova, L. Effective use of CA system for control of water-jet cutting technology. // Advanced Material Research. 853, (2014), pp. 403-408. DOI: 10.4028/www.scientific.net/AMR.853.403

[4] Vasilko, K.; Novák-Marcinčin, J.; Havrila, M. Manufacturing Engineering, 2003, (Slovak)

[5] Hloch, S. et al. Analysis of acoustic emission emerging during hydroabrasive cutting and options for indirect quality control. // International Journal of Advanced Manufacturing Technology. 66, 1-4(2013), pp. 45-48.

[6] Arola, D.; Ramulu, M. Material removal in abrasive waterjet machining of metals surface integrity and texture. // Wear. 210, 1-2(1997), pp. 50-58.

[7] Hassan, A. I.; Chen, C.; Kovacevic, R. On-line monitoring of depth of cut in AWJ cutting. // International Journal of
Machine Tools and Manufacture. 44, 6(2004), p. 595-605. DOI: 10.1016/j.jimachtools.2003.12.002

[8] Hashish, M. A. Model for Abrasive Water Jet Machining, ASME Transactions. // Journal of Engineering Materials and Technology. 111(1989), pp. 154-162. DOI: 10.1115/1.3226448

[9] Hloch, S.; Valíček, J. Topographical anomaly on surfaces created by abrasive waterjet. // The International Journal of Advanced Manufacturing Technology. 59(2012), pp. 593606. DOI: 10.1007/s00170-011-3511-3

[10] Valíček, J. et al.: Experimental analysis of irregularities of metallic surfaces generated by abrasive waterjet. // International Journal of Machine Tools and Manufacture. 47(2007), pp. 1786-1790. 10.1016/j.jmachtools.2007.01.004

[11] Momber, A. W.; Mohan, R. S.; Kovacevic, R. On-line analysis of hydro-abrasive erosion of pre-cracked materials by acoustic emission. // Theoretical and Applied Fracture Mechanics. 31, (1999), pp. 1-17. DOI: 10.1016/S01678442(98)00062-7

[12] Sharma, V.; Chattopadhyaya, S.; Hloch, S. Multi response optimization of process parameters based on Taguchi-Fuzzy model for coal cutting by water jet technology // International Journal of Advanced Manufacturing Technology. 56, 912(2011), pp. 1019-1025.

[13] Hloch, S.; Ruggiero, A. Online monitoring and analysis of hydroabrasive cutting by vibration. // Advances in Mechanical Engineering. 2013, ID 894561, pp. 1-10.

[14] Hloch, S. et al. Water jet technology using in orthopaedic surgery. // Tehnicki vjesnik-Technical Gazette. 20, 2(2010), pp. 351-357.

[15] Hreha, P. et al. Monitoring of focusing tube wear during abrasive waterjet (AWJ) cutting of AISI 309. // Metalurgija. 53, 4(2014), pp. 533-536.

[16] Hloch, S. Dissintegration of bone cement by continual and pulsating water jet. // Tehnicki vjesnik-Technical Gazette. 20, 4(2013), pp. 593-598.

[17] Boud, F.; Carpenter, C.; Folkes, J.; Shipway, P. H. Abrasive waterjet cutting of a titanium alloy: The influence of abrasive morphology and mechanical properties on workpiece grit embedment and cut quality. // Journal of Materials Processing Technology. 210, (2010), pp. 21972205. DOI: 10.1016/j.jmatprotec.2010.08.006

[18] Azmir, M. A.; Ahsan, A. K. Investigation on glass/epoxy composite surfaces machined by abrasive water jet machining. // Journal of materials processing technology. 198, (2008), pp. 122-128. DOI: 10.1016/j.jmatprotec.2007.07.014

[19] Mohan, R. S.; Momber, A. W.; Kovacevic, R. Detection of energy absorption during abrasive water jet machining using acoustic emission. // MED-vol. 2-1, ASME, New York, pp. 69-85.

[20] Kovacevic, R. Monitoring the depth of abrasive waterjet penetration. // International Journal of Machine Tools and Manufacture. 32, 5(1992), pp. 725-736. DOI: 10.1016/08906955(92)90026-D

[21] Arulu, S.; Vijayaraghavan, L.; Malhotra, S. K. Online monitoring of acoustic emission for quality control in drilling of polymeric composites. // Journal of Materials Processing Technology. 185, 1-3(2007), pp. 184-190.

[22] Paul, S.; Hoogstrate A. M.; van Luttervelt, C. A.; Kals H. J. J. Analytical modelling of the totall depth of cut in the abrasive water jet machining of polycristalline brittle material. // Journal of Materials Processing Technology. 73, 1-3(1998), pp. 206-212.

[23] Dasgupta, R. et al. Mechanism of material removal under highstress abrasive wear conditions under varying experimental conditions. // Journal of Materials Science Letters. 20, (2001), pp. 1837-1839. DOl: 10.1023/A:1012889432540 
[24] Neelesh, K. J.; Vijay, K. J. Modeling of material removal inmechanical type advanced machining processes: a state of theart review // Int. J. Mach.Tools Manuf. (2001), pp. 15731635 .

[25] Folkes, J. Waterjet -An innovative tool for manufacturing. // Journal of Materials Processing Technology. 209, (2009), pp. 6181-6189. DOI: 10.1016/j.jmatprotec.2009.05.025

[26] Valíček, J.; Hloch, S. Using the acoustic sound pressure level for quality prediction of surfaces created by abrasive waterjet. // The International Journal of Advanced Manufacturing Technology. 48, 1-4(2011), pp. 193-203.

[27] Asraf, I.; Hassan, A.I.; Chen, C.; Kovacevic, R. On-line monitoring of depth of cut in AWJ cutting. // International Journal of Machine Tools \& Manufacture. 44, 6(2004), pp. 595-605. DOI: 10.1016/j.jmachtools.2003.12.002

[28] Hreha, P. et al. Investigation of sandwich material surface created by abrasive water jet (AWJ) via vibration emission. // Metalurgija. 53, 1(2014), pp. 29-32.

[29] Hreha, P.; Hloch, S. Potential use of vibration for metrology and detection of surface topography created by abrasive waterjet. // International Journal of Surface Science and Engineering. 7, 2(2013), pp. 135-151. DOI: 10.1504/IJSURFSE.2013.053699

[30] Hreha, P.; Hloch, S.; Peržel, V. Analysis of acoustic emission recorded during monitoring of abrasive waterjet cutting of stainless steel AISI 309. // Tehnicki vjesnik-Technical Gazette. 19, 2(2012), pp. 355-359

[31] Chao, J.; Geskin, E. Experimental Study of the Striation Formation and Spectral Analysis of the Abrasive Waterjet Generated Surfaces. $/ / 7^{\text {th }}$ American Water Jet Conference, Seattle, Washington, 1993, pp. 27-41.

[32] Ativitavas, N. Acoustic emission signature analysis of failure mechanisms in fiber reinforced plastic structured, dissertation thesis, Austin 2002. URL: http://www.learningace.com/doc/1984637/5d18ef5625d68a c1045d872e79f538c9/ativitavasn029

\section{Authors' addresses}

\section{Daniel Kinik}

Faculty of Manufacturing Technologies

of Technical University in Košice with the seat in Prešov

Bayerova 1, 08001 Prešov, Slovak Republic

E-mail: daniel@kinik.sk

\section{Beáta Gánovska}

Faculty of Manufacturing Technologies of Technical University in Košice with the seat in Prešov

Bayerova 1, 08001 Prešov, Slovak Republic

E-mail: aksvonag@gmail.com

\section{Sergej Hloch}

Faculty of Manufacturing Technologies

of Technical Universtity of Košice with a seat in Prešov

Bayerova 108001 Prešov, Slovak Republic

Institute of Geonics AS CR, v. v. i.

Studentska 1768 ,

70800 Ostrava-Poruba, Czech Republic

E-mail: hloch.sergej@gmail.com

\section{Peter Monka}

Faculty of Manufacturing Technologies

of Technical University in Košice with the seat in Prešov

Bayerova 1, 08001 Prešov, Slovak Republic

E-mail: peter.monka@tuke.sk

\section{Katarína Monková}

Faculty of Manufacturing Technologies

of Technical University in Košice with the seat in Prešov

Bayerova 1, 08001 Prešov, Slovak Republic

E-mail: katarina.monkova@tuke.sk

\section{Zuzana Hutyrova}

Faculty of Manufacturing Technologies

of Technical University in Košice with the seat in Prešov Bayerova 1, 08001 Prešov, Slovak Republic

E-mail: zuzana.hutyrova@tuke.sk 